\title{
The Mediating Role of Innovation Capability on the Relationship between Strategic Agility and Organizational Performance
}

\author{
Ibrahim Rashed AlTaweel ${ }^{1}$ and Sulieman Ibraheem Al-Hawary ${ }^{2, *}$ \\ 1 Department of Business Administration, Faculty of Business School, Qassim University, P.O. Box 6502, \\ Al Russ 51452, Saudi Arabia; toiel@qu.edu.sa \\ 2 Department of Business Administration, Faculty of Economics and Administrative Sciences, \\ Al al-Bayt University, P.O. Box 130040, Mafraq 25113, Jordan \\ * Correspondence: dr_sliman@yahoo.com
}

Citation: AlTaweel, I.R.; Al-Hawary, S.I. The Mediating Role of Innovation Capability on the Relationship between Strategic Agility and Organizational Performance. Sustainability 2021, 13, 7564. https:// doi.org/10.3390/su13147564

Academic Editors: Christian Vandenberghe and Donato Morea

Received: 21 April 2021

Accepted: 24 June 2021

Published: 6 July 2021

Publisher's Note: MDPI stays neutral with regard to jurisdictional claims in published maps and institutional affiliations.

Copyright: (C) 2021 by the authors Licensee MDPI, Basel, Switzerland. This article is an open access article distributed under the terms and conditions of the Creative Commons Attribution (CC BY) license (https:// creativecommons.org/licenses/by/ $4.0 /)$.

\begin{abstract}
The changes in the business environment and the increase in competition have led organizations to focus greatly on improving their organizational performance in order to achieve a sustainable competitive advantage by relying on keeping pace with these changes and developing their innovation capability to meet their customers' desires. Therefore, this research paper aims to explore the relationship between strategic agility and organizational performance through the mediating role of innovation capability. The research population consisted of senior managers in industrial corporations, and the sample comprised 224 senior managers. Structural equation modeling (SEM) was used as a statistical method for testing hypotheses. The results showed that there is a significant influence of strategic agility on organizational performance and innovation capability. Furthermore, innovation capability plays a mediating role in improving the relationship between strategic agility and organizational performance. Accordingly, a set of recommendations are provided to corporations' senior managers for supporting the organizational activities that lead to the creation of new products and services that are appropriate to the general context of the development of customer desires, realizing the importance of the corporation acquiring flexible re-sources that can be reallocated to meet the changes in the business environment, and adopting modern business models based on stimulating collaborative work and adopting creative ideas.
\end{abstract}

Keywords: strategic agility; innovation capability; organizational performance; corporations

\section{Introduction}

Organizations strive to improve their performance. To this end, numerous means have been suggested, such as maximizing market share, profits, and customer outcomes like satisfaction [1]. In fact, organizational performance as a multidimensional construct is open to be influenced by various exogenous constructs, such as leadership style [2], the organization's strategic choice [3], technological assets [4], and strategic agility [5,6]. According to Qalati et al. (2021), organizational performance is a function of organizational, environmental, and technological factors [7]. On the other hand, it was observed that the relationship between some variables and organizational performance is mediated by other variables such as innovation capability [8], organizational innovation [4], and social media [7]. However, one of the most critical factors hindering organizational performance is a turbulent business environment [6]. Such an environment is characterized by high levels of change and uncertainty [9].

For organizations to survive and grow in turbulent and competitive business environments, adaptation to change should be a first priority [10-12]. One essential method that organizations should adopt is strategic agility $[13,14]$. Agility refers to the core abilities that organizations show to cope with dynamic business environments; these abilities allow an organization to sense, adapt, and respond to such environments [15]. Strategically, agile organizations are sensitive to market changes and available opportunities, able to 
reorganize their resources rapidly to exploit those opportunities, and work with collective commitment to avoid slack responses due to internal conflicts [16].

Numerous positive outcomes of strategic agility have been recognized in the literature, such as boosting an organization's ambidexterity [17], strengthening its performance [18], improving its long-term effectiveness [19], as well as furthering its ability to gain a competitive advantage [20]. Furthermore, organizations are required to deliver compatible products to meet customers' reformed requirements [21] through developing innovation capabilities [22-24]. Innovation capability, as measured by product and process innovation, was identified as a significant predictor of organizational performance in [25].

In summary, organizations that make every effort to advance their performance should keep in view focal constructs such as strategic agility and innovation capability. Despite the considerable delivery of research on these three variables, there is little knowledge of the impact of strategic agility on organizational performance through innovation capability, particularly within the Middle East business environment. Hence, the main contribution of this research paper is the provision of a methodological framework to fill this gap in the literature. It focuses on corporations listed on the ASE as one of the leading stock exchanges in the Middle East region.

\section{Theoretical Background and Research Hypotheses}

\subsection{Strategic Agility}

Strategic agility refers to a set of activities implemented by organizations to add value in volatile and unforecastable business environments [26]. According to Sampath and Krishnamoorthy (2017), strategic agility as a meta-capability is related to the assignment of appropriate resources to improve distinctive competencies among an organization's functions in line with maintaining agility to ensure a balance of competencies over time [27]. Doz (2020) emphasized that strategic agility helps organizations to avoid "rigidity traps" and over-focusing on external embeddedness by moving to prohibit organizational recession and orienting toward more operational flexibility [28-30]. The conditions of stock exchanges make organizations subject to uncertain and oscillatory environments, and thus strategic agility is regarded as a precious capability that enables organizations to cope with these challenges through rapid turnaround via modifying their processes and structures systematically.

In the modern model context anchored on business environment dynamism, Doz and Kosonen (2010) viewed strategic agility as a vital capability adopted by organizations to formulate and modify their business model to become more interactive [16]. The authors argue that there are three exceptional capabilities of strategic agili-ty: (a) strategic sensitivity, (b) resource fluidity, and (c) leadership unity. Strategic sensitivity plays a fundamental role in increasing the ability to recognize the surrounding environment and sense its changes, whether they are opportunities that organizations can exploit or threats that they can avoid through planning and future prediction activities and the development of alternatives to face possible scenarios $[29,31]$. Resource fluidity is related to organizational capabilities to reshape and acquire a set of new resources and capabilities that help organizations to add value for customers and shift towards contemporary business models [16]. Resource fluidity has an effect on the short-term capabilities of organizations, as represented by operational capabilities, and has a long-term and strategic effect on the organizational and structural capabilities of organizations [5]. Leadership unity refers to "one of the administrative response features of the business environment dynamics" [14]. It represents leaders' support of policies, cooperation and collective commitment, in addition to stimulating decision-taking processes more quickly, where time plays an important role in such a rapidly changing environment [32-34]. Shirey (2015) added that the importance of leadership unity lies in focusing on opening effective communication channels between the various administrative levels in organizations [35]. 


\subsection{Innovation Capability}

Most of the countries around the world and organizations that seek excellence and leadership in their industrial sector allocate huge budgets for innovation that are mainly based on research and development processes because of their impact on accelerating the pace of growth and prosperity [36,37]. However, innovation is related to the availability of a set of innovative capabilities and the desire of individuals or organizations to translate creative theoretical ideas into practice [38]. Ferreira et al. (2020) labeled innovation capabilities as complex activities that contribute to the generation and acceptance of new ideas to give rise to a set of products, services, or business models [39]. Ganguly et al. (2020) defined innovation capabilities as the ability to compose and manage resources to produce a range of novel products and services [40]. Lumpkin and Dess (2015) described such capabilities as a part of "the cultural openness to innovation" that organizations adapt by relying on mobilizing energies and skills then directing them towards building an advanced business model or providing creative and competitive products and services, and it is an essential part of entrepreneurship [41].

A resource-based view (RBV) suggests that collaborative innovation helps in obtaining a sustainable competitive advantage [42]. Two major dimensions are used to measure this type of innovation: (a) product innovation capability, and (b) process innovation capability [43-45]. Product innovation capability refers to the extent to which organizations can develop their tangible and intangible resources [46]. Product innovation capability allows organizations to provide new offers that include a set of creative products and services or that have been developed to meet customer desires [45,47]. The second dimension, process innovation capability, refers to the ability to change the methods and techniques used by organizations to present these offers [47]. This dimension reflects organizations' ability to develop new inputs or processes within their production or organizational activities, including information flow, resources, specifications, and tasks, which are employed together to provide the best offers in terms of quality or cost [45].

\subsection{Organizational Performance}

In the general business context, the management of organizations compares their planned goals with the actual results of their work. Thus, organizational performance emerges as one of the managerial concepts for which researchers have unanimously agreed on its importance in identifying the results of organizations $[48,49]$. Organizational performance has been defined as the ability of an organization to achieve its planned goals through the effective and efficient exploitation of available resources [50]. Further, Zhou et al. (2019) considered it as a measurement and analysis system for work outputs, by which stake-holders are able to address deficiencies [51]. Indeed, the indicators used to measure organizational performance in the academic and practical fields vary. Examples of organizational performance measures include market performance and return on investment [52]; effectiveness and efficiency [53]; indicators of financial performance like sales return, investment return, and equity return; as well as indicators of non-financial performance such as customer satisfaction [54]. Following [55,56], organizational performance was measured in the current research as a whole variable using a set of indicators to determine the performance of corporations in the ASE.

\subsection{Strategic Agility, Innovation Capability, and Organizational Performance}

Organizations that carry out their activities within volatile and highly turbulent work environments need to maintain good performance and build a sustainable competitive advantage to face changes in those environments. The idea of strategic agility emerged as one of the ingredients that enable organizations to face changing working conditions by relying on enhancing sensing capabilities and resources reconfiguration $[17,30,33]$. Studies have proven that agile organizations respond more quickly to exploit the opportunities of the work environment. That is, strategic agility enables organizations to improve their financial performance [5,14], increase their market share [17], and improve the effectiveness and 
efficiency of resources by restructuring them in harmony with ambient conditions $[19,57]$. Therefore, the first research hypothesis was:

Hypothesis 1 (H1). Strategic agility has a positive influence on organizational performance.

Moreover, organizations' activities directed to developing innovation capability can be supported by adopting working methods based on strategic agility. Farhana and Swietlicki (2020) emphasized that strategic agility by following up and evaluating changes in work environment conditions enables organizations to add value for customers through prospecting on the untapped market opportunities that contribute to satisfying the desires of customers [17,58]. Kohtamäki et al. (2020) conceptualized strategic agility in innovation through three major practices related to the generation of proactive ideas, value-based product development, as well as product commercialization based on a market-oriented strategy [59]. For Olaleye et al. (2021), innovation capability as evaluated by product and process innovation is positively related to strategic agility, where the latter significantly mediates the relationship between innovation capability and organizational resilience [60]. Cai et al. (2019) argued that innovation capability requires a sufficient flexibility in an organization's resources that can be allocated or reallocated to support initiatives directed to develop new offers [61]. On the other hand, Brand et al. (2021) indicated that strategic agility supports organizations' ability to create innovative business models through organizational restructuring, improving teamwork styles and reducing the impact of the organization's internal policy problems and organizational conflicts [62]. Hence, the second research hypothesis can be formulated as follows:

Hypothesis 2 (H2). Strategic agility has a positive influence on innovation capability.

Organizations have three organizational capabilities: adaption capability, absorption capability, and innovation capability [12]. Maldonado-Guzmán et al. (2019) concluded that innovation capability represents the most important organizational capability because it enables an organization to respond effectively and efficiently to fluctuations in the work environment [63]. The ability of organizations to develop new products and services and generate creative business models is one of the fundamental approaches for obtaining the best organizational results [64]. Such developed products and services increase an organization's ability to expand its market share to exceed those of competitors [65], and can also improve the investment return and sales return, which is reflected in the rates of growth and profitability [66]. Besides, the ability to create new administrative manners and establish novel business models enhancing the efficient and optimal use of organizational resources is highly beneficial [44,58]. Phankhong et al. (2017) stressed that innovation is the distinguishing feature in improving organizational performance through focusing on continuous development activities and increasing the productivity of production elements [67]. Thereby, it was postulated that:

Hypothesis 3 (H3). Innovation capability has a positive influence on organizational performance.

Atieno and Senaji (2017) praised the role that strategic agility plays in improving the performance of organizations by stimulating a sense of timing, which constitutes a milestone as the early or late presentation of organizations' offers leads to a decrease in efficiency and the maximization of costs [68]. Clauss et al. (2019) argued that organizational performance is significantly related to the ability to manage resources to ensure the achievement of effectiveness and harmony with the change in customer requirements [32]. Furthermore, Vaillant and Lafuente (2019) indicated that the ability to adapt to the conditions of the work environment, the possession of flexible resources that can be reconfigured to enhance the innovation ability, a collective commitment to achieving strategic goals, and research and development activities have crucial effects on the provision of a variety of sophisticated products and services [57]. In addition, organizations that always strive 
to keep pace with the change in customer desires by relying on unique offers of goods and services have a greater market share than their competitors, achieve high financial returns, and their customers are loyal to their products, which leads to the improvement of their organizational performance [39]. Accordingly, the fourth research hypothesis can be formulated as follows:

Hypothesis 4 (H4). Innovation capability has a mediating influence on the relationship between strategic agility and organizational performance.

Figure 1 shows the proposed model, which indicates the hypothetical relationships between strategic agility as an independent variable, organizational performance as a dependent variable, and innovation capability as a mediating variable.

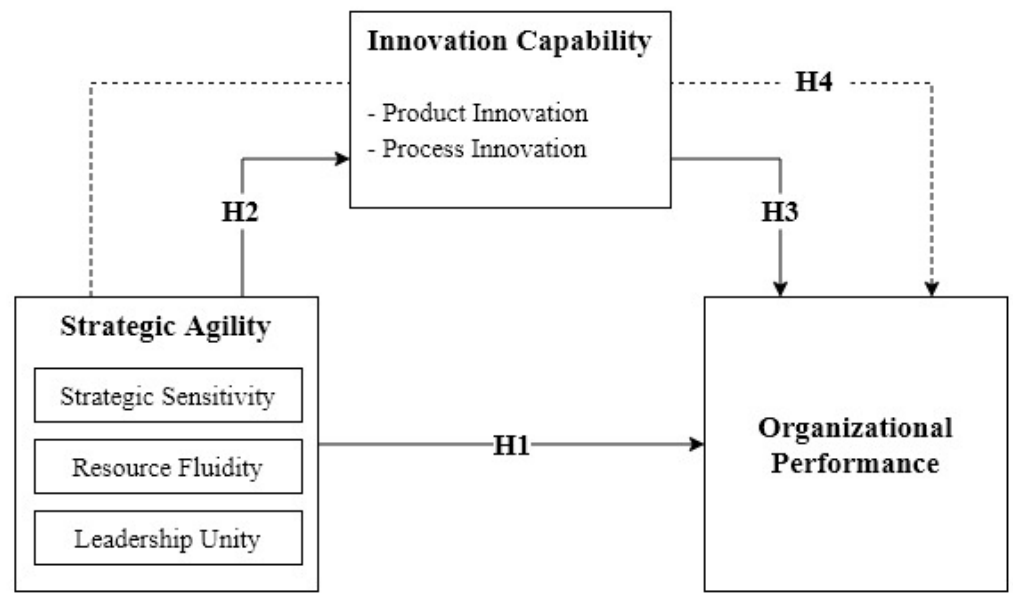

Figure 1. Research framework.

\section{Research Methodology}

\subsection{Population and Sample}

The ASE is considered one of the most significant stock exchanges in which securities are traded in the Arab world, and provides the appropriate environment to ensure the interaction of supply and demand for securities and to establish the foundations of transparent and fair trading. The tasks of the ASE are summarized as providing the necessary systems for implementing and controlling the exchange process, as well as defining the standards of professional conduct and preparing reports that include all the exchange activities. This stock exchange consists of three main sectors: First, the financial sector, which constitutes $53.4 \%$ of the total stock exchange, as real estate corporations are among the most important corporations of this sector, where they reached 32 corporations. Second, the services sector, in which the number of listed corporations has reached 44 , most of which work in commercial services (i.e., $22.7 \%$ of this sector). Finally, the industrial sector, which represents $21.9 \%$ of the ASE. The most important corporations operating in this sector include food industry corporations as well as mining and extraction corporations.

Senior managers working in the corporations listed on the ASE represent the current research population. The sample encompassed 370 senior managers. Data were collected using an electronic self-reported questionnaire designed through Google Forms. It was sent by e-mail to a purposive sample. The number of questionnaires answered by the sample reached 249 questionnaires; out of these, 224 questionnaires were valid for statistical analysis, with a response rate of $60.54 \%$.

The analysis results related to the demographic and functional variables showed that most of the senior managers were males (63.39\%) compared to females (36.61\%). Moreover, most of the sample members had from 15 to 20 years of job experience within the category $(43.75 \%)$, while the last rank percentage was for the category with less than 10 years of job experience $(6.25 \%)$. Regarding education level, most of the senior managers were holders 
of a postgraduate degree (48.21\%), and most of them belonged to the age group from 30 to 40 years $(41.07 \%)$ compared to the lowest age group of less than 30 years $(15.62 \%)$.

\subsection{Research Instrument}

The questionnaire is considered one of the main and most common tools used for collecting data related to social and managerial studies [69,70]. The questionnaire used for the current study consisted of four sections. The first section was devoted to collecting data on subjects' personal characteristics (e.g., gender, job experience, education level, age group). Other sections were used to measure research variables. The questionnaire was designed using a five-point Likert scale $(1=$ strongly disagree; $5=$ strongly agree).

Strategic Agility: SAG represents the second-order independent construct of this research. It was measured through 15 items in accordance with $[5,16,28]$. SAG is divided into three first-order constructs: strategic sensitivity was measured using 5 items (SSE1SSE5). Examples of statements include "My corporation anticipates future customer needs". Resource fluidity was assessed using 5 items (RFL1-RFL5). An example of these items is "My corporation uses multiple business models for different market segments or products". Leadership unity was evaluated by 5 items (LUN1-LUN5). One example is "My corporation's leaders engage in open dialogue and welcome differences of opinion".

Innovation Capability: ICA represents the second-order mediate construct of this research. It was measured through 11 items in accordance with $[39,45]$. ICA is divided into two first-order dimensions: product innovation and process innovation. The first dimension was measured using 5 items (PDI1-PDI5), such as "My corporation often develops new products and services well accepted by the market". The second dimension was evaluated through 6 items (PCI1-PCI6). An example of these items is "My corporation often tries improving operational procedures to hasten the realization of the corporation's goals".

Organizational Performance: OPE represents the first-order dependent construct of this research, which was measured through 9 items (OPE1-OPE9) in accordance with [48]. OPE was measured statements including "My corporation's shares value significantly improved in the last two years", "My corporation has a good reputation in comparison with the competitors".

\subsection{Data Analysis Procedures}

The current research relied on the approach of covariance-based structural equation modeling (CB-SEM) using AMOS 24.0 software. This approach enables the researcher to test hypotheses and identify the causal relationships between the research constructs [71]. For CB-SEM, data should be normally distributed and the sample size should not be less than 200 respondents. This lies in contrast to the partial least squares estimation of structural equation modeling (PLS-SEM) approach that uses the bootstrapping technique to generate data, which limits the ability to generalize the search results [72]. SPSS 24.0 software was used to conduct the descriptive analysis of research constructs and address common method bias. Harman's one-factor analysis was used to identify the total variance extracted in case of one factor extraction through dimension reduction in SPSS [73]. The results indicated that the percentage of variance was 12.173, which is less than 0.50 [74]. MacKenzie and Podsakoff (2012) indicated that procedural remedies can be used to mitigate the problem of common method bias [75]. That is, the design of the study should increase respondents' motivation to provide accurate responses and to avoid stylistic answers. For the current study, respondents were asked to complete questions on their firms. All of them were senior managers and aware of their firms' strategic agility, innovation capabilities, and organizational performance. Additionally, the questionnaire was revised to ensure that it was free from ambiguous statements so that it was understandable. 


\section{Research Findings \\ 4.1. Measurement Model Estimation}

Before starting to test the research hypotheses, the instructions presented in [76] were followed to determine the validity and reliability of the research measurement model using confirmatory factor analysis (CFA). Table 1 shows factor loadings on their first-order latent constructs and the values of average variance extracted (AVE) for each construct to identify the convergent validity. It also illustrates the results of the discriminant validity test by comparing the values of maximum shared variance (MSV) with the values of AVE, as well as the square root of average variance extracted with the correlation between constructs. Moreover, McDonald's omega coefficients were used to test the composite reliability (CR) of the measurement model.

Table 1. The validity and reliability of the measurement model.

\begin{tabular}{|c|c|c|c|c|c|c|c|c|c|c|c|c|}
\hline \multirow{2}{*}{ Constructs } & \multirow{2}{*}{ Mean } & \multirow{2}{*}{ SD } & \multirow{2}{*}{ Loadings } & \multirow{2}{*}{ AVE } & \multirow{2}{*}{ MSV } & \multirow{2}{*}{ CR } & \multicolumn{6}{|c|}{ Correlation } \\
\hline & & & & & & & 1 & 2 & 3 & 4 & 5 & 6 \\
\hline 1. Strategic Sensitivity (SSE) & 3.63 & 0.80 & $0.68-0.77$ & 0.53 & 0.42 & 0.85 & 0.728 & & & & & \\
\hline 2. Resource Fluidity (RFL) & 3.71 & 0.88 & $0.67-0.76$ & 0.52 & 0.39 & 0.85 & 0.544 & 0.726 & & & & \\
\hline 3. Leadership Unity (LUN) & 3.50 & 0.93 & $0.67-0.78$ & 0.53 & 0.43 & 0.85 & 0.612 & 0.430 & 0.713 & & & \\
\hline 4. Product Innovation (PDI) & 3.69 & 0.91 & $0.68-0.75$ & 0.51 & 0.50 & 0.84 & 0.538 & 0.506 & 0.622 & 0.716 & & \\
\hline 5. Process Innovation (PCI) & 3.74 & 0.86 & $0.66-0.75$ & 0.51 & 0.49 & 0.86 & 0.412 & 0.391 & 0.485 & 0.373 & 0.717 & \\
\hline 6. Organizational Performance (OPE) & 3.58 & 0.79 & $0.68-0.77$ & 0.54 & 0.51 & 0.91 & 0.387 & 0.627 & 0.493 & 0.662 & 0.528 & 0.737 \\
\hline
\end{tabular}

Note: Bold fonts in the table refer to the root square of average variance extracted (AVE).

The results of Table 1 show that all items had loading values on their constructs within the range $0.668-0.782$, which is greater than 0.50 , the minimum value for retaining the item $[77,78]$. The values of AVE ranged between 0.513 and 0.543 (greater than 0.50, the lowest acceptable value to judge the convergent validity) [79]. The table also shows that the values of MSV were smaller than the values of AVE, and the values of the square root of average variance extracted were greater than the correlation between other research constructs. These results indicate that the measurement model fulfills the conditions of discriminant validity [80]. Further, the values of McDonald's omega coefficients were greater than 0.70 , which represents the minimum threshold for achieving composite reliability [81].

\subsection{Descriptive Analysis}

The results related to means values, standard deviations, as well as the correlation coefficients for this study's first-order constructs are presented in Table 1. The table shows that the general level of strategic agility of the corporations listed on ASE was moderate $(\mathrm{M}=3.61)$, where the resource fluidity dimension ranked first with a high level $(\mathrm{M}=3.71$, $\mathrm{SD}=0.884$ ), while the leadership unity dimension had the lowest rank, which was moderate level $(\mathrm{M}=3.50, \mathrm{SD}=0.925)$. Additionally, the general level of innovation capability of the corporations listed on ASE was high $(\mathrm{M}=3.71)$, where the process innovation had the first rank $(\mathrm{M}=3.74, \mathrm{SD}=0.857)$ and the product innovation had the second rank $(\mathrm{M}=3.69, \mathrm{SD}=0.908)$. The organizational performance of the corporations listed on ASE was moderate $(\mathrm{M}=3.58)$.

Moreover, the results in Table 1 indicate that there was a correlation between strategic agility dimensions and the innovation capability dimension, where the correlation coefficients were within the range $r=0.373-0.622$. Further, the correlation coefficients between strategic agility and organizational performance ranged between 0.387 and 0.627 , and the correlation coefficients between innovation capability and organizational performance were between $r=0.528$ and $r=0.662$. The correlation coefficients among strategic agility dimensions ranged within $0.430-0.612$, indicating that the research data were free of a multicollinearity problem because of all internal correlation values were less than 0.80 [76]. 


\subsection{Structural Model}

The structural model shown in Figure 2 was used to show the extent of the goodnessof-fit indices. The ratio of chi-square to degrees of freedom was 2.227, which is less than the upper permissible threshold of 3 [69]. The values of GFI, CFI, and TLI were greater than the lowest acceptable value of 0.90 [82]; the value of RMSEA was 0.039, which is less than the highest permissible threshold of 0.08 [83]. Thus, it can be considered the structural model used to test research hypotheses had good indexes to generalize the results.

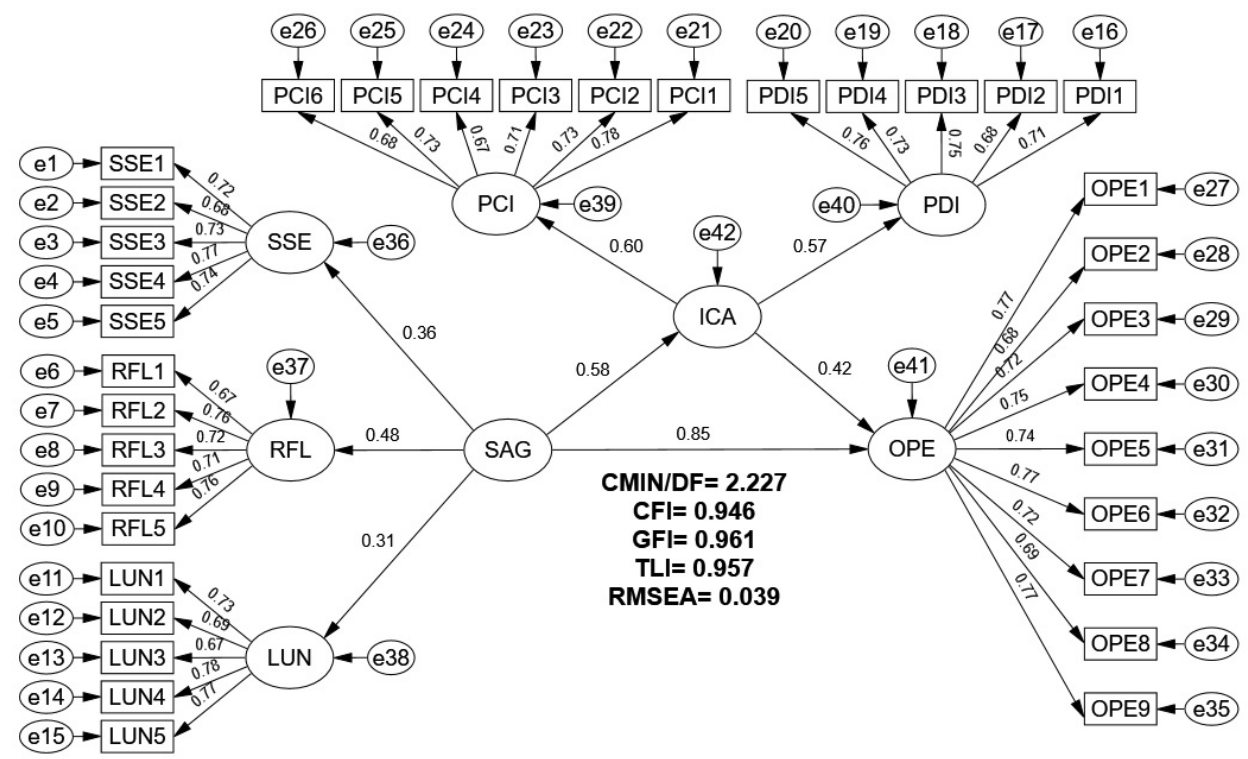

Figure 2. Standardized coefficients of the structural model.

Table 2 lists the results of the standard coefficients along with the probability levels. The results indicate that strategic agility had a direct positive influence on organizational performance, based on the probability level which was less than 0.05 and the standard influence coefficient $\beta=0.620$. Strategic agility had a direct positive influence on innovation capability, where the probability level testing this hypothesis was less than 0.05 and the standard influence value $\beta=0.581$.

Table 2. Results of research hypotheses testing.

\begin{tabular}{|c|c|c|c|c|}
\hline \multirow{2}{*}{ Hypo. } & \multirow{2}{*}{ Effect Path } & \multicolumn{3}{|c|}{ Standardized Effect Coefficients } \\
\hline & & Total & Direct & Indirect \\
\hline H1 & Strategic Agility $\rightarrow$ Organizational Performance & $0.620^{* * *}$ & $0.620^{* * *}$ & - \\
\hline $\mathrm{H} 2$ & Strategic Agility $\rightarrow$ Innovation Capability & $0.581 * * *$ & $0.581 * * *$ & - \\
\hline H3 & Innovation Capability $\rightarrow$ Organizational Performance & $0.424 * *$ & $0.424^{* *}$ & - \\
\hline $\mathrm{H} 4$ & Strategic Agility $\rightarrow$ Innovation Capability $\rightarrow$ Organizational Performance & $0.849 *$ & $0.603 *$ & $0.246^{*}$ \\
\hline
\end{tabular}

Note: ${ }^{*} p<0.05,{ }^{* *} p<0.01,{ }^{* * *} p<0.001$.

The results of the table also confirm that the innovation capability had a direct positive impact on the organizational performance $(\beta=0.424, p<0.05)$. Moreover, innovation capability improved the total influence between strategic agility and organizational performance $(\beta=0.849)$, with a direct effect $(\beta=0.603, p<0.05)$ and an indirect effect $(\beta=0.246$, $p<0.05)$. Thus, innovation capability played a significant mediating role between strategic agility and organizational performance.

\section{Results Discussion}

The main purpose of this research was to discover the mediating role of innovation capability on the relationship between strategic agility and organizational performance 
in the corporations listed on the ASE. The results of the research showed that the level of strategic agility and organizational performance in these corporations was moderate, which is consistent with the findings of some previous studies [32,34,54]. The level of innovation capability was high, and this result corresponds to those obtained in $[43,45]$. Therefore, the management of corporations listed on the ASE is aware of the critical importance of providing unique products and services to their customers, and adopts contemporary management approaches that assist them in research and development processes to keep pace with customers' desires. Furthermore, these corporations seek to adapt to the changes in the work environment through the acquisition of organizational resources that are flexible enough and by sensing opportunities and threats in the work environment in a proactive way in order to be able to develop appropriate scenarios for these changes.

In terms of its hypotheses, this study sought to test three hypothetical influences as stated in $\mathrm{H} 1, \mathrm{H} 2$, and $\mathrm{H} 3$. $\mathrm{H} 1$ assumed that strategic agility has a significant influence on organizational performance, while $\mathrm{H} 2$ suggested that strategic agility has a significant influence on innovation capability. Finally, H3 postulated that innovation capability has a significant influence on organizational performance. Firstly, the results indicated that strategic agility has a positive influence on organizational performance. This result can be explained by the fact that organizations that adopt agile strategies based on developing practical scenarios derived from sensing changes in the business environment have greater opportunities to improve their financial position, achieve customer satisfaction, and gain the largest market share compared to their competitors. In line with [62], the results revealed that strategic agility had a positive influence on innovation capability. Prior works in this regard asserted the role that strategic agility played in improving organizational performance. Such works indicated that strategic agility assists organizations in sensing their environments for changes and opportunities, to adapt and respond quickly and utilize their resources effectively and efficiently $[5,14,17,19,30,32,33,57]$.

Secondly, the results revealed that there is a significant influence of strategic agility on innovation capability. This result suggests that the ultimate aim of innovation capability can be achieved through strategic agility, which allows organizations to be aware of their market changes and customer needs. Hence, strategic agility is viewed as a prerequisite of innovation capability [15]. The specific contribution of strategic agility to innovation capability can be explained through the exceptional capabilities of strategic agility, which are recognizing the external environment via strategic sensitivity, acquiring new resources or reshaping current resources (resource fluidity), and total commitment to face external challenges (leadership unity) [16,27-29].

Thirdly, the results pointed out that innovation capability has a positive influence on organizational performance, which is consistent with the results of [44]. Thus, organizations' ability to modify their administrative methods and orientation towards contemporary business models, which are considered to provide novel products and services and develop new uses for existing products, leads organizations to achieve their strategic goals effectively and efficiently. Finally, it was found that the innovation capability has a significant mediating influence on the relationship between strategic agility and organizational performance. That is, the total effect of strategic agility on organizational performance increased with the introduction of innovation capability, which transmits the effect of strategic agility to organizational performance. In other words, strategic ability equips an organization with information about the market, and the customers and innovation capability enable an organization to develop new processes or inputs and create creative products [45,47]. Therefore, organizations' awareness of the importance of predicting changes in the business environment and reallocating available resources in proportion to the exploitation of opportunities and avoiding threats improves their ability to create products and services that meet the desires of customers. This ultimate aim can be achieved through a contemporary management approach that supports continuous development activities, which is reflected in improving productivity, building a wide base of loyal customers and achieving an increase in returns in the long term. 


\section{Contributions to the Literature}

This study contributes to the literature on strategic agility, innovation capability, and organizational performance in several ways. First, the study shows that strategic sensitivity, resource fluidity, and leadership unity are crucial strategic components for improving organizational performance. Strategic sensitivity allows organizations to distinguish market opportunities and assess the suitability of their internal strengths to exploit these opportunities. Resource liquidity refers to the extent of resource flexibility that enables an organization to adjust its resources and the way they are used in line with its priorities. Moreover, the ongoing collective commitment of the management (i.e., leadership unity) helps an organization to expand its ability to adapt to environmental changes. The role of the leadership here is to make the right decisions at the right time.

These three components play a central role in boosting organizational performance. In the context of industrial organizations, taking advantage of opportunities often means introducing new products. Achieving this goal not only requires the availability of resources, but also flexibility in their use, in terms of resource allocation and reallocation according to demand. The picture is not complete without the collective administrative orientation and the speed of decision-making.

Second, the study signifies that strategic agility is a main prerequisite of innovation capability. The most important implicit feature of strategic agility is the ability to integrate resources, which is crucial to encourage innovation. Innovation here refers to transforming ideas into new processes or products. The ability to innovate is itself a dynamic ability that means harnessing new knowledge to respond to change in an organization's environment by focusing on existing resources and processes. The role of strategic agility here is to determine the nature of the environmental change and the form of the optimal response. The problem that firms face in this regard is that they are able to respond to the change in the environment, but the response they offer is inappropriate. Here, the importance of strategic agility appears, as it determines market needs that have not yet been met. Both strategic agility and innovation capability are complementary features of ambidextrous firms.

Third, it is well established that strategic agility improves organizational performance, but new insight is brought by the knowledge that strategic agility suits various environmental changes. This depends on the nature of the market opportunities. One type of change requires enhancing the capabilities of an organization by providing other dynamic capabilities such as the ability to innovate, while other types mean making minor adjustments to the products in order to meet the demands of the moment in the market. In both cases, strategic agility plays an important role. Thus, this study contributes to the literature of sustainability, as it shows that dynamic capabilities such as strategic agility and innovation capability assist organizations in achieving supportable performance.

\section{Managerial Implications}

The piece of information that managers miss is not that innovation capability leads to better performance, but how innovation capability can be developed. The current study shows that innovation is continuous because the environment in which an organization operates is constantly changing. The most important characteristic of innovation capability is the flexibility to adapt to that change. For an organization to maintain an active state of innovation adequacy, it must provide a guide that directs innovation to the path of success. This guide is strategic agility.

On the other hand, the response to environmental changes depends on the nature of the change itself. Some changes require an organization to make improvements to existing products, and some require the introduction of new products with completely different characteristics. The organization in the second case must be more capable of innovating.

Accordingly, managers who seek to improve organizational performance must take the nature of changes and market opportunities into consideration. The nature of these changes and opportunities determines the nature of the response. Continuous improvement of the product itself is a form of response, and changing the whole characteristics of the product 
is another form of response. Sometimes, an organization has strategic agility and the ability to innovate, but it fails to improve its organizational performance due to its inability to determine the appropriate response.

Moreover, an organization must determine the appropriate way to improve performance in light of its assessment of market needs. If an organization realizes that improving performance is through a rapid response by introducing new products, the way it exploits the capabilities of agility and innovation is different from improving performance through improving existing products. Both strategic agility and innovation capability are essential to elevate organizational performance; however, the optimal mix of these capabilities is subject to the method of performance enhancement.

\section{Limitations and Future Directions}

Although this research dealt with vital variables in the science of strategic management, there were a set of limits that should be considered in future studies. First, there was a need to expand the study of strategic agility in order to define theoretical frameworks and discover the practical implications of organizations adopting this strategy in the volatile business market. Secondly, future studies should consider that this research was implemented in Jordan, which is a developing country; hence, future studies should go towards conducting such research in emerging and developed countries in order to discover the perspective of strategic agility. Last but not least, future studies should try to identify the impact of strategic agility on managerial and economic variables such as entrepreneurial orientation, sustainable competitive advantage, and organizational prowess in order to present a set of proposals that lead to organizational development.

Author Contributions: Conceptualization, I.R.A. and S.I.A.-H.; supervision, S.I.A.H.; methodology, S.I.A.-H.; software, S.I.A.-H.; validation, I.R.A. and S.I.A.-H.; formal analysis, S.I.A.-H.; investigation, I.R.A.; resources, I.R.A.; data curation, S.I.A.-H.; writing-original draft preparation, I.R.A. and S.I.A.-H.; writing-review and editing, I.R.A. and S.I.A.-H.; visualization, S.I.A.-H. Both authors have read and agreed to the published version of the manuscript.

Funding: This research received no external funding.

Institutional Review Board Statement: Not applicable.

Informed Consent Statement: Not applicable.

Data Availability Statement: Not applicable.

Conflicts of Interest: The authors declare no conflict of interest.

\section{References}

1. Colquitt, J.; LePine, J.A.; Wesson, M.J. Organizational Behavior: Improving Performance and Commitment in the Workplace, 6th ed.; McGraw-Hill Education: New York, NY, USA, 2019.

2. Kim, M.S.; Thapa, B. Relationship of ethical leadership, corporate social responsibility and organizational performance. Sustainability 2018, 10, 447. [CrossRef]

3. Ceptureanu, S.I.; Ceptureanu, E.G.; Marin, I. Assessing the Role of Strategic Choice on Organizational Performance by JacqueminBerry Entropy Index. Entropy 2017, 19, 448. [CrossRef]

4. García-Sánchez, E.; García-Morales, V.J.; Martín-Rojas, R. Influence of technological assets on organizational performance through absorptive capacity, organizational innovation and internal labour flexibility. Sustainability 2018, 10, 770. [CrossRef]

5. Kale, E.; Aknar, A.; Başar, Ö. Absorptive capacity and firm performance: The mediating role of strategic agility. Int. J. Hosp. Manag. 2019, 78, 276-283. [CrossRef]

6. Arokodare, A. Strategic agility: Achieving superior organizational performance through strategic foresight. Glob. J. Manag. Bus. Res. 2020, 20, 6-16.

7. Qalati, S.A.; Li, W.; Ahmed, N.; Mirani, M.A.; Khan, A. Examining the factors affecting SME performance: The mediating role of social media adoption. Sustainability 2021, 13, 75. [CrossRef]

8. Park, K.O. How CSV and CSR affect organizational performance: A productive behavior perspective. Int. J. Environ. Res. Public Health 2020, 17, 2556. [CrossRef] [PubMed]

9. Nashiruddin, M.I. Understanding the Turbulence of Business Environment in Telecom Industry: Empirical Evidence from Indonesia. Bul. Pos Dan Telekomun. 2018, 16, 75-90. [CrossRef] 
10. Dess, G.G.; McNamara, G.; Eisner, A.B.; Lee, S.H. Strategic management: Text \& Cases, 9th ed.; McGraw-Hill Education: New York, NY, USA, 2019.

11. Miceli, A.; Hagen, B.; Riccardi, M.P.; Sotti, F.; Settembre-Blundo, D. Thriving, Not Just Surviving in Changing Times: How Sustainability, Agility and Digitalization Intertwine with Organizational Resilience. Sustainability 2021, 13, 2052. [CrossRef]

12. Battour, M.; Barahma, M.; Al-Awlaqi, M. The Relationship between HRM Strategies and Sustainable Competitive Advantage: Testing the Mediating Role of Strategic Agility. Sustainability 2021, 13, 5315. [CrossRef]

13. Shams, R.; Vrontis, D.; Believer, Z.; Ferraris, A.; Czinkota, M.R. Strategic agility in international business: A conceptual framework for "agile" multinationals. J. Int. Manag. 2021, 27, 100737. [CrossRef]

14. Bondzi-Simpson, P.E.; Agomor, K.S. Financing public universities in Ghana through strategic agility: Lessons from Ghana institute of management and public administration (GIMPA). Glob. J. Flex. Syst. Manag. 2021, 22, 1-15. [CrossRef]

15. Iddris, F.; Baffour, G.A.; Abraha, D.G. The role of innovation capability in achieving supply chain agility. Int. J. Manag. Comput. Sci. 2014, 4, 104-112.

16. Doz, Y.L.; Kosonen, M. Embedding Strategic Agility: A Leadership Agenda for Accelerating Business Model Renewal. Long Range Plan. 2010, 43, 370-382. [CrossRef]

17. Clauss, T.; Kraus, S.; Kallinger, F.L.; Bican, P.M.; Brem, A.; Kailer, N. Organizational ambidexterity and competitive advantage: The role of strategic agility in the exploration-exploitation paradox. J. Innov. Knowl. 2020. [CrossRef]

18. Gerald, E.; Obianuju, A.; Chukwunonso, N. Strategic agility and performance of small and medium enterprises in the phase of Covid-19 pandemic. Int. J. Financ. Account. Manag. 2020, 2, 41-50. [CrossRef]

19. Al-Tameemi, A.H.; Abd-Alghafur, Q.A. The effect of strategic agility on organizational effectiveness Applied research at the Central Bank of Iraq. Tikrit J. Adm. Econ. Sci. 2020, 16, 322-341.

20. Nkuda, M. Strategic Agility and Competitive Advantage: Exploration of the Ontological, Epistemological and Theoretical Underpinnings. Br. J. Econ. Manag. Trade 2017, 16, 1-13. [CrossRef] [PubMed]

21. Kodama, M. Collaborative Dynamic Capabilities for Service Innovation: Creating a New Healthcare Ecosystem, 1st ed.; Palgrave Macmillan: London, UK, 2018.

22. Donkor, J.; Donkor, G.N.A.; Kankam-Kwarteng, C.; Aidoo, E. Innovative capability, strategic goals and financial performance of SMEs in Ghana. Asia Pac. J. Innov. Entrep. 2018, 12, 238-254. [CrossRef]

23. Sahoo, S. Quality management, innovation capability and firm performance: Empirical insights from Indian manufacturing SMEs. TQM J. 2019, 31, 1003-1027. [CrossRef]

24. Falahat, M.; Ramayah, T.; Soto-Acosta, P.; Lee, Y.-Y. SMEs internationalization: The role of product innovation, market intelligence, pricing and marketing communication capabilities as drivers of SMEs' international performance. Technol. Forecast. Soc. Chang. 2020, 152, 119908. [CrossRef]

25. Kijkasiwat, P.; Phuensane, P. Innovation and firm performance: The moderating and mediating roles of firm size and small and medium enterprise finance. J. Risk Financ. Manag. 2020, 13, 97. [CrossRef]

26. Chan, C.M.L.; Teoh, S.Y.; Yeow, A.; Pan, G. Agility in responding to disruptive digital innovation: Case study of an SME. Inf. Syst. J. 2019, 29, 436-455. [CrossRef]

27. Sampath, G.; Krishnamoorthy, B. Is strategic agility the new Holy Grail? Exploring the strategic agility construct. Int. J. Bus. Excell. 2017, 13, 160-180. [CrossRef]

28. Doz, Y. Fostering strategic agility: How individual executives and human resource practices contribute. Hum. Resour. Manag. Rev. 2020, 30, 1-14. [CrossRef]

29. Fakunmoju, S.; Arokodare, M.; Makinde, G. Strategic Agility and Competitive Advantage of Oil and Gas Marketing Companies: The Moderating Effect of Information Technology Capability and Strategic Foresight. J. Account. Manag. 2020, 10, 97-113.

30. Pereira, V.; Mellahi, K.; Temouri, Y.; Patnaik, S.; Roohanifar, M. Investigating dynamic capabilities, agility and knowledge management within EMNEs-longitudinal evidence from Europe. J. Knowl. Manag. 2019, 23, 1708-1728. [CrossRef]

31. Reed, J.H. Strategic agility and the effects of firm age and environmental turbulence. J. Strategy Manag. 2020, 14, 129-149. [CrossRef]

32. Clauss, T.; Abebe, M.; Tangpong, C.; Hock, M. Strategic Agility, Business Model Innovation, and Firm Performance: An Empirical Investigation. IEEE Trans. Eng. Manag. 2019, 68, 1-18. [CrossRef]

33. Cunha, M.P.E.; Gomes, E.; Mellahi, K.; Miner, A.S.; Rego, A. Strategic agility through improvisational capabilities: Implications for a paradox-sensitive HRM. Hum. Resour. Manag. Rev. 2020, 30, 100695. [CrossRef]

34. Khaddam, A.A. Impact of personnel creativity on achieving strategic agility: The mediating role of knowledge sharing. Manag. Sci. Lett. 2020, 10, 2293-2300. [CrossRef]

35. Shirey, M.R. Strategic Agility for Nursing Leadership. J. Nurs. Adm. 2015, 45, 305-308. [CrossRef] [PubMed]

36. Miranda, A.L.B.B.; Nodari, C.H.; Nobre, L.H.N.; Schmidt, S. Analysis of The Correlation Between The Companies' Investment in Research, Development and Profitability, and The Countries' Competitiveness and Innovation Capability. Rev. Tecnol. 2020, 20, 35-58. [CrossRef]

37. Ngo, Q.T.; Nguyen, A.T.; Doan, N.P.; Nguyen, T.D. Do technology transfer, R\&D collaboration and cooperation matter for R\&D along the supply chain? Evidence from Vietnamese young SMEs. Uncertain Supply Chain. Manag. 2020, 8, 513-522. [CrossRef]

38. Bedford, A.; Ma, L.; Ma, N.; Vojvoda, K. Patenting activity or innovative originality? Account. Financ. 2020, 12730. [CrossRef] 
39. Ferreira, J.; Coelho, A.; Moutinho, L. Dynamic capabilities, creativity and innovation capability and their impact on competitive advantage and firm performance: The moderating role of entrepreneurial orientation. Technovation 2020, 92, 102061. [CrossRef]

40. Ganguly, A.; Kumar, C.; Saxena, G.; Talukdar, A. Firms' Reputation for Innovation: Role of Marketing Capability, Innovation Capability, and Knowledge Sharing. J. Inf. Knowl. Manag. 2020, 19, 2050004. [CrossRef]

41. Lumpkin, G.T.; Dess, G.G. Entrepreneurial Orientation. In Wiley Encyclopedia of Management; Editor, Cary Cooper; John Wiley \& Sons, Ltd.: Chichester, West Sussex, UK, 2014; pp. 1-4. [CrossRef]

42. Aas, T.H.; Breuning, K.J. Conceptualizing Innovation Capabilities: A Contingency Perspective. J. Entrep. Manag. Innov. 2017, 13, 7-24. [CrossRef]

43. Lei, H.; Nguyen, T.T.; Le, P.B. How knowledge sharing connects interpersonal trust and innovation capability: The moderating effect of leadership support. Chin. Manag. Stud. 2019, 13, 276-298. [CrossRef]

44. Migdadi, M.M. Knowledge management processes, innovation capability and organizational performance. Int. J. Product. Perform. Manag. 2020. [CrossRef]

45. Najafi-Tavani, S.; Najafi-Tavani, Z.; Naudé, P.; Oghazi, P.; Zeynaloo, E. How collaborative innovation networks affect new product performance: Product innovation capability, process innovation capability, and absorptive capacity. Ind. Mark. Manag. 2018, 73, 193-205. [CrossRef]

46. Hsiao, Y.C.; Hsu, Z.X. Firm-specific advantages-product innovation capability complementarities and innovation success: A core competency approach. Technol. Soc. 2018, 55, 78-84. [CrossRef]

47. Aljanabi, A.R.A. The role of innovation capability in the relationship between marketing capability and new product development: Evidence from the telecommunication sector. Eur. J. Innov. Manag. 2020. [CrossRef]

48. Rehman, S.U.; Mohamed, R.; Ayoup, H. The Mediating Role of Organizational Capabilities between Organizational Performance and its Determinants. J. Glob. Entrep. Res. 2019, 9, 1-23. [CrossRef]

49. Wang, T.; Wu, J.; Gu, J.; Hu, L. Impact of open innovation on organizational performance in different conflict management styles: Based on resource dependence theory. Eur. J. Innov. Manag. 2020, 32, 199-222. [CrossRef]

50. Muthuveloo, R.; Shanmugam, N.; Teoh, A.P. The impact of tacit knowledge management on organizational performance: Evidence from Malaysia. Asia Pac. Manag. Rev. 2017, 22, 192-201. [CrossRef]

51. Zhou, S.S.; Zhou, A.J.; Feng, J.; Jiang, S. Dynamic capabilities and organizational performance: The mediating role of innovation. J. Manag. Organ. 2019, 25, 731-747. [CrossRef]

52. Mehralian, G.; Nazari, J.A.; Ghasemzadeh, P. The effects of knowledge creation process on organizational performance using the BSC approach: The mediating role of intellectual capital. J. Knowl. Manag. 2018, 22, 802-823. [CrossRef]

53. Chakraborty, D.; Biswas, W. Articulating the value of human resource planning (HRP) activities in augmenting organizational performance toward a sustained competitive firm. J. Asia Bus. Stud. 2020, 14, 62-90. [CrossRef]

54. Pang, K.; Lu, C.S. Organizational motivation, employee job satisfaction and organizational performance: An empirical study of container shipping companies in Taiwan. Marit. Bus. Rev. 2018, 3, 36-52. [CrossRef]

55. Khan, H.R.; Ali, M.; Olya, H.G.T.; Zulqarnain, M.; Khan, Z.R. Transformational leadership, corporate social responsibility, organizational innovation, and organizational performance: Symmetrical and asymmetrical analytical approaches. Corp. Soc. Responsib. Environ. Manag. 2018, 25, 1270-1283. [CrossRef]

56. Subramony, M.; Segers, J.; Chadwick, C.; Shyamsunder, A. Leadership development practice bundles and organizational performance: The mediating role of human capital and social capital. J. Bus. Res. 2018, 83, 120-129. [CrossRef]

57. Vaillant, Y.; Lafuente, E. The increased international propensity of serial entrepreneurs demonstrating ambidextrous strategic agility: A precursor to international marketing agility. Int. Mark. Rev. 2019, 36, 239-259. [CrossRef]

58. Farhana, M.; Swietlicki, D. Dynamic Capabilities Impact on Innovation: Niche Market and Startups. J. Technol. Manag. Innov. 2020, 15, 83-96. [CrossRef]

59. Kohtamäki, M.; Heimonen, J.; Sjödin, D.; Heikkilä, V. Strategic agility in innovation: Unpacking the interaction between entrepreneurial orientation and absorptive capacity by using practice theory. J. Bus. Res. 2020, 118, 12-25. [CrossRef]

60. Olaleye, B.; Anifowose, O.; Efuntade, A.; Arije, B. The role of innovation and strategic agility on firms' resilience: A case study of tertiary institutions in Nigeria. Manag. Sci. Lett. 2021, 11, 297-304. [CrossRef]

61. Cai, Z.; Liu, H.; Huang, Q.; Liang, L. Developing organizational agility in product innovation: The roles of IT capability, KM capability, and innovative climate: Developing organizational agility in product innovation. RED Manag. 2019, 49, 421-438. [CrossRef]

62. Brand, M.; Tiberius, V.; Bican, P.M.; Brem, A. Agility as an innovation driver: Towards an agile front end of innovation framework. Rev. Manag. Sci. 2021, 15, 157-187. [CrossRef]

63. Maldonado-Guzmán, G.; Garza-Reyes, J.A.; Pinzón-Castro, S.Y.; Kumar, V. Innovation capabilities and performance: Are they truly linked in SMEs? Int. J. Innov. Sci. 2019, 11, 48-62. [CrossRef]

64. Puspita, L.E.; Christiananta, B.; Ellitan, L. The effect of strategic orientation, supply chain capability, innovation capability, on competitive advantage, and performance of furniture retails. Int. J. Sci. Technol. Res. 2020, 9, 4521-4529.

65. Al-Hawary, S.I.S.; Batayneh, A.M.I. A Study of the Strategic Performance of Shareholding Industrial Organizations in Jordan: Using Z- Score Model. Int. J. Bus. Soc. Sci. 2015, 6, 177-182.

66. Valmohammadi, C.; Sofiyabadi, J.; Kolahi, B.A. How do Knowledge Management Practices Affect Sustainable Balanced Performance? Mediating Role of Innovation Practices. Sustainability 2019, 11, 5129. [CrossRef] 
67. Phankhong, T.; Abu Bakar, L.J.; Poespowidjojo, D.A.L. The Mediating effect of Innovativeness on Innovation Strategy, Atmosphere, Culture and Organizational Performance: Proposed theoretical Framework. Int. J. Econ. Res. 2017, 14, 359-369.

68. Atieno, O.J.; Senaji, T.A. Relationship Between Strategic Agility and Organization Performance. Afr. Int. J. Manag. Educ. Gov. $2017,2,73-79$.

69. Al-Hawary, S.I.S.; Al-Namlan, A.A. Impact of Electronic Human Resources Management on the Organizational Learning at the Private Hospitals in the State of Qatar. Glob. J. Manag. Bus. Res. Adm. Manag. 2018, 18, 1-11.

70. Saunders, M.N.K.; Lewis, P.; Thornhill, A. Research Methods for Business Students, 8th ed.; Pearson Education: London, UK, 2019.

71. Collier, J.E. Applied Structural Equation Modeling Using AMOS: Basic to Advanced Techniques, 1st ed.; Routledge: New York, NY, USA, 2020.

72. Zhang, M.F.; Dawson, J.F.; Kline, R.B. Evaluating the Use of Covariance-Based Structural Equation Modelling with Reflective Measurement in Organizational and Management Research: A Review and Recommendations for Best Practice. Br. J. Manag. 2020, 32, 257-272. [CrossRef]

73. Kang, D.; Kim, S. Conceptual model development of sustainability practices: The case of port operations for collaboration and governance. Sustainability 2017, 9, 2333. [CrossRef]

74. Ma, A.T.; Chow, A.S.; Cheung, L.T.; Lee, K.M.; Liu, S. Impacts of tourists' sociodemographic characteristics on the travel motivation and satisfaction: the case of protected areas in South China. Sustainability 2018, 10, 3388. [CrossRef]

75. MacKenzie, S.B.; Podsakoff, P.M. Common method bias in marketing: Causes, mechanisms, and procedural remedies. J. Retail. 2012, 88, 542-555. [CrossRef]

76. Hair, J.F.; Page, M.; Brunsveld, N. The Essentials of Business Research Methods, 4th ed.; Routledge: New York, NY, USA, 2019.

77. Al-Lozi, M.S.; Almomani, R.Z.Q.; Al-Hawary, S.I.S. Impact of Talent Management on Achieving Organizational Excellence in Arab Potash Company in Jordan. Glob. J. Manag. Bus. Res. Adm. Manag. 2017, 17, 15-25.

78. Alolayyan, M.N.; Al-Hawary, S.I.S.; Mohammad, A.A.S.; Al-Nady, B.A.A. Banking Service Quality Provided by Commercial Banks and Customer Satisfaction. A structural Equation Modelling Approaches. Int. J. Product. Qual. Manag. 2018, 24, 543-565. [CrossRef]

79. Sung, K.S.; Yi, Y.G.; Shin, H.I. Reliability and validity of knee extensor strength measurements using a portable dynamometer anchoring system in a supine position. BMC Musculoskelet. Disord. 2019, 20, 320. [CrossRef]

80. Rimkeviciene, J.; Hawgood, J.; O'Gorman, J.; De Leo, D. Construct Validity of the Acquired Capability for Suicide Scale: Factor Structure, Convergent and Discriminant Validity. J. Psychopathol. Behav. Assess. 2017, 39, 291-302. [CrossRef]

81. Bebba, I.; Bentafat, A.; Al-Hawary, S.I.S. The Reality of Algerian Universities Doctoral Students Configuration. Glob. J. Manag. Bus. 2017, 17, 21-33.

82. Keith, T.Z. Multiple Regression and Beyond: An Introduction to Multiple Regression and Structural Equation Modeling, 3rd ed.; Routledge: New York, NY, USA, 2019.

83. Sardeshmukh, S.R.; Vandenberg, R.J. Integrating Moderation and Mediation: A Structural Equation Modeling Approach. Organ. Res. Methods 2017, 20, 721-745. [CrossRef] 